\title{
Development of physical fitness and its sexual difference in well-trained, highly skilled junior competitive swimmers
}

\author{
Shinichi Demura ${ }^{1}$ \\ ジュニア競泳選手の体力の発達と性差 \\ 出 村 慎 一1) \\ 要䄪
}

本研究の目的は，十分トレーニンクを穔んた12葴から19歳の競泳選手延べ277名を対象として，加 踰に伴ら体力の発達及びその性差を明らかにすることであった．被検者はいずれも，国体候補選手と して選抜された技能の高い選手で，彼らは 3 年間に渡り，週 5 日，平妁 1 日5000 $\mathrm{m}$ 以上のハードな 競涾トレーニンクを行った. 3 年間の継綂的体力測定（年 2 回）によって得られた繾断的・横断的資 料（51变量）に基ついて，形態，筇力，神経機能，柔㜞性，及び心肺機能の各体力領域別に検討が なされた．統計的分析の結果，体格，静的筋力，六ワー，敏捷性，平衡性，有酸素能力，及び無酸素 能力の多くの体力要因においてて，同年代の一般人の同様な加柃に伴う発達や性差が確認された。 しか し，躯幹の屈曲柔軟性や体重当たりの有酸素性能力には有意な性差や加踰に伴5発達が認めら九なか った。 また体脂肪は少なく，局や足首の柔㜞性は優九，性差も認められたが，加龄に伴ら有意な発達 的変化は認められなかった。従って，これらの体力要因については，一般人の場合と異なる発達傾向 があると考えられ，これは比較的長期間に渡るハードな継続的競泳トレーニンクの影慗によると推測 された。

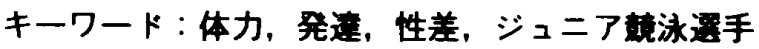

(Japan J. Phys. Educ. 40: 40-53, May, 1995)

Key words: physical fitness, development, sexual difference, junior competitive swimmers

\section{Introduction}

Each athletic sport has its own characteristics as its achievement-form varies. Specific physical fitness elements are strongly related to the achievement of each sport, and the degree of their contribution differs in each sport. Therefore, by continuing the training of a certain exer- cise for a long period of time as a special sport, abilities relating strongly to the achievement of its exercise will be developed. On the other hand, if a person with an excellent aptitude for a certain sport trains at it long as a special event, abilities relating strongly to the achievement of this sport will be developed further.

It seems that various factors like physical, mental, environmental, technical, and other elements, are related to the achievement of swimming, but among them the contribution of the physical factor is greatest because swimming is an individual
1）金沢大学教育学部 干920-11 金沢市角間町
1. Faculty of Education, Kanazawa University, Kakuma-town, Kanazawa, Ishikawa (920-11) 
sport. Until now, various studies comparing physical fitness between well-trained swimmers and ordinary people $\mathrm{e}^{9,21,26)}$, on the relations between swimming performances and physical fitness elements $8,15-23,25,40,44)$, on physical fitness characteristics of well-trained swimmers or highlyskilled swimmers ${ }^{18,20,24)}$, and on physical effects of swimming training or practice $11,12,28,30,39,43)$, have been conducted. But few studies have been conducted systematically on the development of the total physical fitness with age and its sex difference in well-trained, young swimmers during growth.

The purpose of this study was to determine the growth and development of physique and physical fitness and its sex difference in well-trained and highly-skilled young swimmers continuing hard-swimming training over several years.

\section{Methods}

\section{A. Subjects}

Subjects were young competitive swimmers aged 12-19 years. They began swimming practice or training from a preschool stage or early stage of elementary school. They had very high swimming skill already at the beginning of this experiment, and performed hard swimming training over 5 days a week, $5000 \mathrm{~m}$ a day on the average for at least 3 years. Sample sizes were a total of 277 and physical fitness measurements were taken 6 times for 3 years (twice a year). To examine the influence of hard swimming training on physical fitness properly, physical fitness tests may be desired to be taken a few times a year. However, the enforcement of physical fitness tests selected in this study imposes a considerable physical burden on subjects and it is very difficult

Table 1 Sample sizes by groups and measurement time

\begin{tabular}{|c|c|c|c|c|c|c|c|c|}
\hline \multicolumn{2}{|c|}{$\mathrm{T}(\mathrm{MT})$} & $\mathrm{G} 1$ & G2 & G3 & G4 & G5 & G6 & Total \\
\hline \multirow{8}{*}{ B } & $1(1989.5)$ & 4 & 9 & 7 & 6 & 4 & 4 & 34 \\
\hline & $2(1989.10)$ & 7 & 14 & 5 & 5 & 2 & & 33 \\
\hline & $3(1990.5)$ & & 8 & 8 & 9 & 6 & 6 & 37 \\
\hline & $4(1990.10)$ & & 6 & 8 & 10 & 5 & 1 & 30 \\
\hline & 5 (1991. 4) & & & 3 & 8 & 5 & 4 & 20 \\
\hline & $6(1991.10)$ & & & 1 & 3 & 3 & 3 & 10 \\
\hline & sample sizes & 11 & 37 & 32 & 41 & 25 & 18 & 164 \\
\hline & mean age $(\mathrm{yr})$ & 13.1 & 14.1 & 15.0 & 16.1 & 17.0 & 17.9 & 15.6 \\
\hline \multirow{8}{*}{ G } & $1(1989.5)$ & 7 & 3 & 4 & 4 & & & 18 \\
\hline & $2(1989.10)$ & 7 & 10 & 4 & 3 & 1 & & 25 \\
\hline & $3(1990.5)$ & 2 & 9 & 4 & 3 & 3 & & 21 \\
\hline & $4(1990.10)$ & 3 & 10 & 4 & 3 & 3 & & 23 \\
\hline & 5 (1991. 4) & & 1 & 7 & 2 & & 5 & 15 \\
\hline & $6(1991.10)$ & & 1 & 5 & 1 & 1 & 3 & 11 \\
\hline & sample sizes & 19 & 34 & 28 & 16 & 8 & 8 & 113 \\
\hline & mean age $(\mathrm{yr})$ & 13.1 & 14.1 & 15.0 & 16.1 & 16.9 & 17.9 & 15.0 \\
\hline
\end{tabular}

Note: $\mathrm{B}=$ boys, $\mathrm{G}=$ girls, $\mathrm{T}=$ times, $\mathrm{MT}=$ measurement time (yr.mon)

$12.5 \mathrm{yr}<\mathrm{G} 1 \leqq 13.5 \mathrm{yr}, 13.5 \mathrm{yr}<\mathrm{G} 2 \leqq 14.5 \mathrm{yr}$

$14.5 \mathrm{yr}<\mathrm{G} 3 \leqq 15.5 \mathrm{yr}, 15.5 \mathrm{yr}<\mathrm{G} 4 \leqq 16.5 \mathrm{yr}$

$16.5 \mathrm{yr}<\mathrm{G} 5 \leqq 17.5 \mathrm{yr}, 17.5 \mathrm{yr}<\mathrm{G} 6 \leqq 18.5 \mathrm{yr}$ 
to do measurements during a competitive season. Therefore, physical fitness measurements were taken twice, i.e., before and after real competitive season. Some subjects participated in the first 1 and 2 years and others did in the last 1 and 2 years. Further, Some subjects could not undergo all tests in each measurement because of illness, injury, or for other reasons. The details on the date and sample sizes at each measurement are shown in Table 1. For example, a sample size which is 32 of boys' $\mathrm{G} 3$ in the table means the number of subject's data corresponding to 15 years (14.5-15.5) at the measurement year. Data of some subjects may include in the same agestage twice. Data taken after a half-year in this study were assumed to be independent- and different-individuals' data even if they were from the same subjects because all subjects are during growth and their physical characteristics change remarkably during a short period. Statistical analysis was performed using the above-stated data. Significant differences between age means of each age-group ( $\mathrm{G} 1$ to $\mathrm{G} 6$ in Table 1 ) in both sexes were found, but not between mean ages of the matched age-groups of both sexes. Therefore it was considered that groups G1 to G6 are different in ages, but the mean ages of the matched age groups in both sexes are the same.

\section{B. Test variables}

In general, physical fitness for performance is broadly separated into physique and physical function, and further the latter is divided into functions such as muscle, joint (flexibility), nerve and cardio-vascular system. Fifty-one tests representing each domain were selected by considering conditions like validity, reliability and practicability. All measurements of flexibility were done using an angle-method with high validity and reliability. Maximal physical working capacity ( $\mathrm{PWC}$ max) and maximal oxygen intake
$\left(\mathrm{VO}_{2} \max \right)$ were estimated from heart rates at each working load when a subject did pedal exercise of 50-59 rotations every minute for 9 minutes after resting for one-minute, using a Cateye ergociser produced by Tuyama company. Maximum anaerobic power (MAP) was calculated from load values and rotation numbers, using Power Max V produced by Combi company. For $\mathrm{PWC}, \dot{\mathrm{VO}}_{2}, \mathrm{MAP}$, also the relative values, i.e., values per body weight ( $\mathrm{PWC} / \mathrm{w}, \dot{\mathrm{VO}}_{2} / \mathrm{w}, \mathrm{MAP}$ / w) were calculated. Test methods used to measure physique, muscular function, flexibility and nervous function have been described in previous studies $^{15-18,24)}$ or were general methods ${ }^{32,33,38)}$. Body density, lean body mass (LBM), body surface area (BSA), body fat, and percentage of body fat $(\% \mathrm{BF})$ were calculated using estimated formulas developed by Nagamine ${ }^{35)}$ and Brozek ${ }^{2)}$.

\section{Statistical procedures}

Mean and standard deviation according to sex and age for each variable were calculated and tests of their mean differences (two-way analysis of variance: ANOVA) were done. To make possible examination from the viewpoint of each physical fitness element, factor analysis was applied to each correlation matrix consisting of a variablegroup representing each physical fitness domain, and the extracted physical fitness factors were interpreted. A test of difference of mean factor scores of sex and age differences was done (ANOVA). When significant differences were found in main factors, multiple comparison tests were performed.

\section{Results}

Table 2 shows the mean and standard deviation by sex and the test results of ANOVA for each variable. Table 3 shows the test results of multiple comparison for variables in which significant differences in the main factors of sex and age 


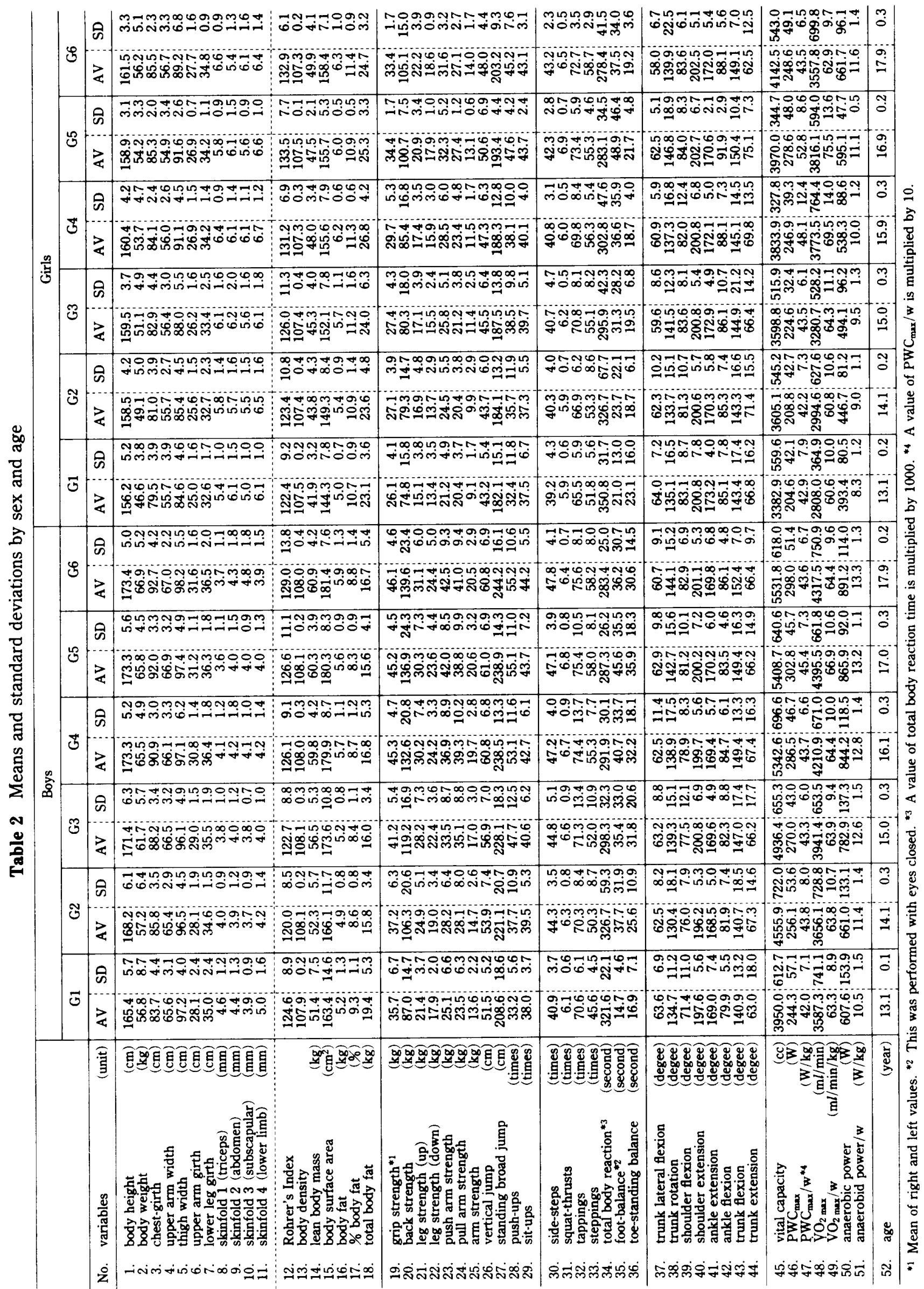


Table 3 Test results of ANOVA (sex and age) and multiple comparison for each variable

\begin{tabular}{|c|c|c|c|c|c|c|c|c|c|}
\hline \multirow[b]{2}{*}{ No. } & \multirow{2}{*}{\multicolumn{2}{|c|}{$\frac{\text { F1 }}{\text { F-value }}$}} & \multirow{2}{*}{$\frac{\text { Total }}{\text { F-value }}$} & \multicolumn{2}{|c|}{ F2 } & \multirow{2}{*}{\begin{tabular}{c|} 
IN \\
F-value
\end{tabular}} & \multicolumn{2}{|c|}{ F2 } & \multirow[b]{2}{*}{ F1 } \\
\hline & & & & $\begin{array}{c}\text { boys } \\
\text { F-value }\end{array}$ & $\begin{array}{c}\text { girls } \\
\text { F-value }\end{array}$ & & boy & girl & \\
\hline \begin{tabular}{r|}
1. \\
2. \\
3. \\
4. \\
5. \\
6. \\
7. \\
8. \\
9. \\
10. \\
11.
\end{tabular} & $\begin{array}{r}247.04^{* *} \\
185.92^{* *} \\
133.27^{* *} \\
396.41^{* *} \\
122.27^{* *} \\
240.57^{* *} \\
50.05^{* *} \\
157.41^{* *} \\
67.23^{* *} \\
92.80^{* *} \\
104.84^{* *}\end{array}$ & $\begin{array}{l}0^{\prime \prime} \\
0^{\circ} \\
0^{\prime \prime} \\
0^{\circ} \\
0^{\circ} \\
0^{\circ} \\
0^{\circ} \\
9 \\
9 \\
9 \\
9\end{array}$ & $\begin{array}{c}7.06^{* *} \\
16.43^{* *} \\
17.49^{* *} \\
0.37 \\
1.70 \\
18.34^{* *} \\
6.30^{* *} \\
0.83 \\
0.31 \\
1.99 \\
1.12\end{array}$ & $\begin{array}{r}7.17^{* *} \\
15.97^{* *} \\
16.82^{* *} \\
\\
23.24^{* *} \\
4.44^{* *}\end{array}$ & $\begin{array}{l}1.51 \\
5.58^{* *} \\
4.65^{* *}\end{array}$ & $\begin{array}{l}1.15 \\
0.58 \\
1.31 \\
0.13 \\
0.51 \\
2.26^{*} \\
0.07 \\
1.72 \\
0.15 \\
0.40 \\
1.15\end{array}$ & $\begin{array}{l}6-3>2-1 \\
6-4>3>2-1 \\
6-4>3>2-1 \\
\\
6-5>3-1 / 3>2 \\
6,4>3-1 / 5>2\end{array}$ & $\begin{array}{l}6-4>2-1 / 6>3 / 3>1 \\
6-3>2-1 \\
\\
6,4>2-1 / 5,3>1 \\
6,4>2-1\end{array}$ & $\begin{array}{l}\mathrm{G} 1-\mathrm{G} 6: B>G \\
\mathrm{G} 1-\mathrm{G} 6: \mathrm{B}>\mathrm{G} \\
\mathrm{G} 1-\mathrm{G} 6: B>\mathrm{G} \\
\mathrm{G} 1-\mathrm{G} 6: \mathrm{B}>\mathrm{G} \\
\mathrm{G} 1-\mathrm{G} 6: \mathrm{B}>\mathrm{G} \\
\mathrm{G} 1-\mathrm{G} 6: \mathrm{B}>\mathrm{G} \\
\mathrm{G} 1-\mathrm{G} 6: \mathrm{B}>\mathrm{G} \\
\mathrm{G} 1-\mathrm{G} 6: \mathrm{B}<\mathrm{G} \\
\mathrm{G} 1-\mathrm{G} 6: \mathrm{B}<\mathrm{G} \\
\mathrm{G} 1-\mathrm{G} 6: \mathrm{B}<\mathrm{G} \\
\mathrm{G} 2-\mathrm{G} 6: \mathrm{B}<\mathrm{G}\end{array}$ \\
\hline $\begin{array}{l}12 . \\
13 . \\
14 . \\
15 . \\
16 . \\
17 . \\
18 .\end{array}$ & $\begin{array}{r}9.94^{* *} \\
185.15^{* *} \\
251.96^{* *} \\
233.53^{* *} \\
6.07^{*} \\
204.49^{* *} \\
151.07^{* *} \\
\end{array}$ & $\begin{array}{l}9 \\
0 \\
0 \\
8 \\
8 \\
8 \\
8 \\
8\end{array}$ & $\begin{array}{c}6.07^{* *} \\
1.98 \\
18.52^{* *} \\
15.25^{* *} \\
2.22 \\
0.79 \\
0.26 \\
\end{array}$ & $\begin{array}{c}2.93^{*} \\
17.70^{* *} \\
14.39^{* *}\end{array}$ & $\begin{array}{l}3.57^{* *} \\
5.74^{* *} \\
4.80^{* *}\end{array}$ & $\begin{array}{l}0.21 \\
0.66 \\
0.71 \\
0.60 \\
0.79 \\
1.69 \\
0.27\end{array}$ & $\begin{array}{l}6-4>2 / 6>1 \\
6-4>3>2-1 \\
6-4>3>2-1\end{array}$ & $\begin{array}{l}6-4>2-1 / 6>3 \\
64>2-1 / 6>3>1 \\
6,4>2-1 / 5,3>1\end{array}$ & $\begin{array}{l}G 1-G 6: B>G \\
G 1-G 6: B>G \\
G 1-G 6: B<G \\
G 1-G 6: B<G \\
G 1-G 6: B<G \\
G 2-G 6: B<G\end{array}$ \\
\hline $\begin{array}{l}19 . \\
20 . \\
21 . \\
22 . \\
23 . \\
24 . \\
25 . \\
26 . \\
27 . \\
28 . \\
29 .\end{array}$ & $\begin{array}{r}283.16^{* *} \\
126.16^{* *} \\
113.06^{* *} \\
135.62^{* *} \\
63.31^{* *} \\
122.39^{* *} \\
250.47^{* *} \\
145.78^{* *} \\
323.93^{* *} \\
18.63^{* *} \\
7.81^{* *}\end{array}$ & 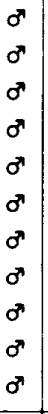 & $\begin{array}{r}17.74^{* *} \\
21.37^{* *} \\
9.82^{* *} \\
15.78^{* *} \\
18.40^{* *} \\
15.97^{* *} \\
26.10^{* *} \\
7.89^{* *} \\
11.72^{* *} \\
11.78^{* *} \\
6.26^{* *} \\
\end{array}$ & $\begin{array}{r}16.08^{* *} \\
17.43^{* *} \\
6.43^{* *} \\
12.99^{* *} \\
19.44^{* *} \\
16.15^{* *} \\
27.23^{* *} \\
8.02^{* *} \\
12.15^{* *} \\
12.05^{* *} \\
4.12^{* *}\end{array}$ & $\begin{array}{l}4.95^{* *} \\
4.64^{* *} \\
2.62^{*} \\
4.65^{* *} \\
3.28^{* *} \\
2.71^{*} \\
6.09^{* *} \\
1.84 \\
1.69 \\
2.27^{*} \\
2.33^{*} \\
\end{array}$ & $\begin{array}{l}1.51 \\
2.39^{*} \\
0.82 \\
0.80 \\
2.05 \\
2.79^{*} \\
2.40^{*} \\
0.75 \\
2.43^{*} \\
1.61 \\
0.15 \\
\end{array}$ & $\begin{array}{l}6-4>3>2-1 \\
6-4>3>2>1 \\
6-3>2-1 \\
6-5>3>2-1 / 4>2-1 \\
6-5>3>2-1 / 6-5>4 \\
6-4>3>2-1 \\
6-4>3>2-1 \\
6-4>3>2-1 \\
6-4>3>1 / 2>1 \\
6-4>3>2-1 \\
6-5>3-1 / 4>2-1\end{array}$ & $\begin{array}{l}6-5>3-1 / 4>1 \\
65>3-1 / 4>1 \\
6-5>2-1 / 6>3 \\
6-4>2-1 / 6>3 \\
6-4>1 / 6>3-2 \\
6-5>2-1 / 6>3 \\
6-3>2-1 / 6>4-3 \\
6-5>2-1 \\
6-5>2-1\end{array}$ & $\begin{array}{l}\text { G1-G6: } B>G \\
\text { G2-G6: } B>G \\
\text { G1-G6: } B>G \\
\text { G1-G6: } B>G \\
\text { G2-G6: } B>G \\
\text { G2-G6: } B>G \\
\text { G1-G6: } B>G \\
\text { G1-G6: } B>G \\
\text { G1-G6: } B<G \\
\text { G2-G3: } B<G \\
\text { G4 } \quad: B<G\end{array}$ \\
\hline $\begin{array}{l}30 . \\
31 . \\
32 . \\
33 . \\
34 . \\
36 .\end{array}$ & $\begin{array}{c}43.62^{* *} \\
5.60^{*} \\
9.74^{* *} \\
1.96 \\
2.03 \\
26.09^{* *}\end{array}$ & $\begin{array}{l}\sigma^{7} \\
\sigma^{\prime \prime} \\
\sigma^{\prime \prime}\end{array}$ & $\begin{array}{l}6.39^{* *} \\
5.31^{* *} \\
1.91 \\
5.72^{* *} \\
8.73^{* *} \\
1.34\end{array}$ & $\begin{array}{l}4.15^{* *} \\
2.34^{*} \\
5.93^{* *} \\
3.94^{* *}\end{array}$ & $\begin{array}{l}1.55 \\
2.54^{*} \\
\\
0.85 \\
5.85^{* *}\end{array}$ & $\begin{array}{l}0.46 \\
0.57 \\
0.12 \\
0.97 \\
0.58 \\
1.08\end{array}$ & $\begin{array}{l}6-4>2>1 / 6>3>1 \\
6-4>2-1 \\
6-4>2-1 / 6-5>3 \\
1-2>6-4 / 2>3\end{array}$ & $\begin{array}{l}5>3-1 / 6>2 \\
1-2>6-3\end{array}$ & $\begin{array}{l}\text { G2-G6: } B>G \\
\text { G2, G4: } B>G \\
G 2: B>G \\
G 2-G 5: B>G\end{array}$ \\
\hline $\begin{array}{l}39 . \\
40 . \\
41 . \\
42 .\end{array}$ & $\begin{array}{c}14.51^{* *} \\
7.66^{* *} \\
5.10^{*} \\
18.65^{* *}\end{array}$ & $\begin{array}{l}9 \\
8 \\
8 \\
8 \\
\end{array}$ & $\begin{array}{l}1.55 \\
1.20 \\
0.31 \\
1.40\end{array}$ & & & $\begin{array}{l}0.97 \\
0.73 \\
0.28 \\
0.24\end{array}$ & & & $\begin{array}{ll}\mathrm{G} 1-\mathrm{G} 3 & : \mathrm{B}<\mathrm{G} \\
\mathrm{G} 2 & : \mathrm{B}<\mathrm{G} \\
\mathrm{G} 3 & : \mathrm{B}<\mathrm{G} \\
\mathrm{G} 3-\mathrm{G} 4: & \mathrm{B}<\mathrm{G}\end{array}$ \\
\hline $\begin{array}{l}45 . \\
46 . \\
48 . \\
50 . \\
51 .\end{array}$ & $\begin{array}{r}180.00^{* *} \\
33.43^{* *} \\
41.48^{* *} \\
284.91^{* *} \\
162.89^{* *}\end{array}$ & $\begin{array}{l}0^{\prime \prime} \\
0^{\prime \prime} \\
0^{\prime \prime} \\
0^{7} \\
0^{7}\end{array}$ & $\begin{array}{r}15.58^{* *} \\
7.56^{* *} \\
7.60^{* *} \\
23.09^{* *} \\
20.25^{* *}\end{array}$ & $\begin{array}{r}15.56^{* *} \\
4.45^{* *} \\
4.85^{* *} \\
21.04^{* *} \\
11.08^{* *}\end{array}$ & $\begin{array}{l}2.15 \\
4.27^{* *} \\
4.59^{* *} \\
5.98^{* *} \\
8.18^{* *}\end{array}$ & $\begin{array}{l}2.89^{*} \\
0.29 \\
0.22 \\
1.30 \\
0.92\end{array}$ & $\begin{array}{l}6-4>3>2>1 \\
6-4>2-1 / 5>3 \\
6-4>2-1 / 6-5>3 \\
6-4>3>2-1 \\
6-3>2-1\end{array}$ & $\begin{array}{l}6-4>2-1 / 4>3 \\
6-4>2-1 / 4>3 \\
6-4>2-1 / 3>1 \\
6-4>2-1 / 3>1 / 6>4\end{array}$ & $\begin{array}{l}\text { G1-G6: } B>G \\
\text { G2-G3, G6: B }>\text { G } \\
\text { G1-G6: B }>\text { G } \\
\text { G1-G6: B }>\text { G } \\
\text { G1-G6: } B>G\end{array}$ \\
\hline 52. & 0.96 & & $1424.1^{* *}$ & $838.14^{* *}$ & $541.07^{* *}$ & 0.35 & $6>5>4>3>2>1$ & $6>5>4>3>2>1$ & \\
\hline
\end{tabular}

1) Groups G1-G6 are the same as those in Table 1 (Numbers $35,37,38,43,44,47$ and 49 are omitted because significant difference in any factor was not found).

2) $\mathbf{F 1}=$ sex difference factor, $\mathbf{F} 2=$ age difference factor, $\mathrm{IN}=$ interaction factor

3) Boys' value for $\sigma^{n}$ and girls' for on are significantly greater, respectively.

4) 6-3>2-1 below F2 means that values of 4 groups of G3-G6 are greater than those of $G 1$ and $G 2.6,4>3-1$ means that values of $\mathrm{G} 6$ and $\mathrm{G} 4$ are greater than those of G1-G3.

5) G1-G6: B > G below F1 means that boys' values (B) in 6 groups of $G 1-G 6$ are greater than girls' (G), G2, G4: B $>$ G means that boys' values in G2 and G4 are greater than girls'. ${ }^{*} \mathrm{p}<0.05,{ }^{* *} \mathrm{p}<0.01$. 
differences were found. All physique measures showed significant sex differences, and values of all variables of body fat were greater in girls as compared with boys. Significant differences in body weight, chest girth, upper arm girth, lower leg girth, Rohrer's Index, LBM, and BSA were found between age-groups of G1-G6 in both sexes, but a significant difference in body height was found only in boys. Significant differences were found mainly between age-groups of $\mathrm{G} 4-\mathrm{G} 6, \mathrm{G} 3$, and age-groups of $\mathrm{G} 1$ and $\mathrm{G} 2$ in boys, and between age-groups of G4-G6 and age-groups of G1 and G2 in girls. There was no significant difference between age-groups in any variable of body width and body fat.

Also in muscular strength domain significant sex differences in all variables were found and boys' values were greater than girls'. Vertical jump and standing broad-jump which measure muscle power did not show significant differences between age-groups only in girls, but the other tests showed it in both sexes. These results were consistent with those in previous studies ${ }^{16,18,20,24)}$ using swimmers as subjects. The test results of multiple comparison showed that significant differences were mainly found between agegroups of G3-G6 or G4-G6, and age-groups of G1-G2 in boys, and between age-groups of G4G6 and age-groups of $\mathrm{G} 1$ and $\mathrm{G} 2$ in girls.

For nervous function domain, significant sex differences were found in tests of side-steps, squat and thrust, finger-tapping, and toe-standing balance with open-eyes: boys scored higher in all tests. Significant differences between age-groups were found in tests of squat and thrust and total body reaction for both sexes, and only in boys in tests of side-steps and stepping. Significant differences in boys were found mainly between agegroups of G4-G6 and age-groups of G1 and G2.

For joint function domain, significant sex differences were found mainly in variables of shoulder and ankle joints, and girls' values were greater than those of boys'. But, variables on trunk bending flexibility hardly showed significant differences. The present results were largely consistent with those in studies ${ }^{18,24)}$ examining flexibility of junior high school competitive swimmers.

For cardio-vascular function domain, significant sex differences were found in vital capacity, $\mathrm{PWC}_{\max }, \dot{\mathrm{VO}}_{2 \max }$ and anaerobic power, but not in $\mathrm{PWC}_{\max } / \mathrm{w}$ or $\mathrm{VO}_{2 \max } / \mathrm{w}$. Significant increases with age were found in all variables except for $\mathrm{PWC}_{\max } / \mathrm{w}$ and $\mathrm{V}_{2 \max } / \mathrm{w}$ in both sexes, and vital capacity only in girls. Significant differences were found mainly between age-groups of $\mathrm{G} 4-\mathrm{G} 6, \mathrm{G} 3$, and age-groups of $\mathrm{G} 1$ and $\mathrm{G} 2$ in boys, and mainly between age-groups of $\mathrm{G} 4-\mathrm{G} 6$, and age-groups of G1 and G2 in girls.

As already stated in the statistical procedures section, factor analysis was applied to each correlation matrix consisting of a variable-group representing each physical fitness domain. Figure 1 presents the mean scores by sex- and agegroups of interpreted factors with pole graphes and the test results of the mean differences. Estimation equations of factors were drawn based on the completed estimation method. For physique domain, 11 variables except for composite variables (numbers 12 to 18 in Table 2) were used for this analysis. For joint function domain, the test of difference of mean factor scores was not performed because the interpretation of factors extracted was difficult, in addition to which no significant changes with age were found in any variables (see Table 2). Furthermore, for this domain, it seemed that an examination of sex and development differences is possible from the results shown in Table 2, because each test such as trunk flexion, ankle extension, and shoulder flexion, shows concrete measurement content of each joint flexibility, respectively.

As shown in figure 1, for physique domain, phy- 
sique factor and body fat factor were interpreted. The former was defined by a set of variable-group representing the whole physique of body linearity, body bulk, and body weight, and the latter was defined mainly by skinfold variables. Significant sex differences in both factors were found, but significant growth with age was found only for the physique factor. In muscular strength domain, muscular endurance factor defined by push-ups and sit-ups, and static strength-muscle power factor defined by variables representing static strength and muscular power were interpreted. Significant sex differences in 2 factors were found, but significant development with age was found only in boys. For nervous function domain, 3 factors of balance, agility of total body, and agility of lower limbs were interpreted. Significant sex differences in the former 2 factors were found, and significant development with age was found in both sexes in agility of total body, and only in boys in agility of lower limbs. For cardio-vascular function domain, aerobic ability and anaerobic ability factors were interpreted, and a significant sex and development differences were found only in the latter.

\section{Discussion}

\section{A. Physique domain}

Demura et al. ${ }^{24)}$ determined that male competitive swimmers as compared with ordinary people of a similar age have superior physique and less body fat. From comparing body height, body

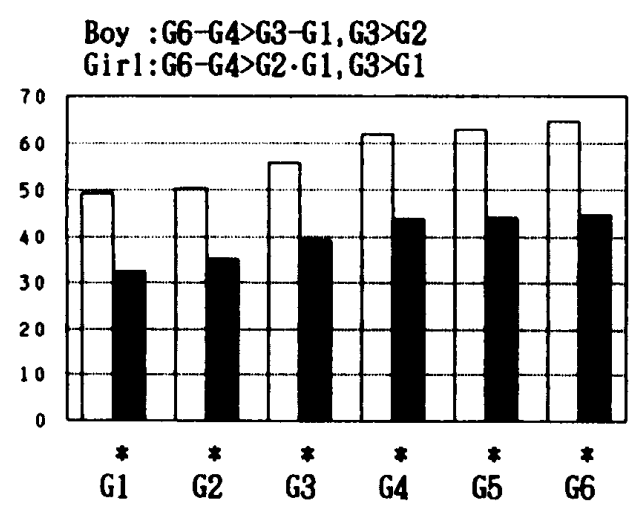

$F 1=177.11^{* *}, F 2=13.25^{* *}$, IN $=0.28$

Physique

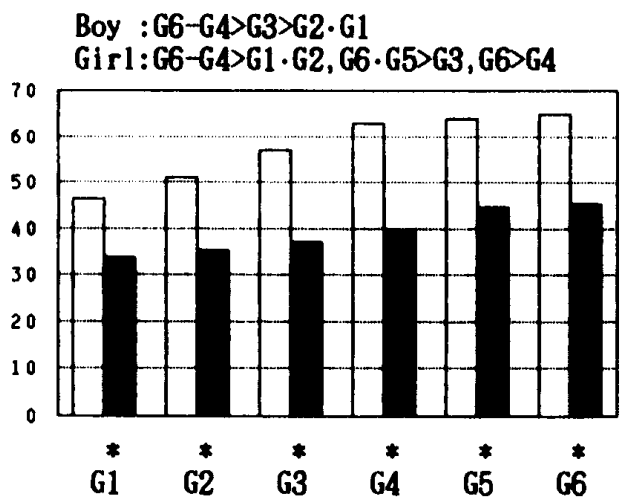

$\mathrm{F} 1=392.61^{* *}, \mathrm{~F} 2=28.79^{* *}, \mathrm{IN}=2.74^{*}$

uscular strength and power

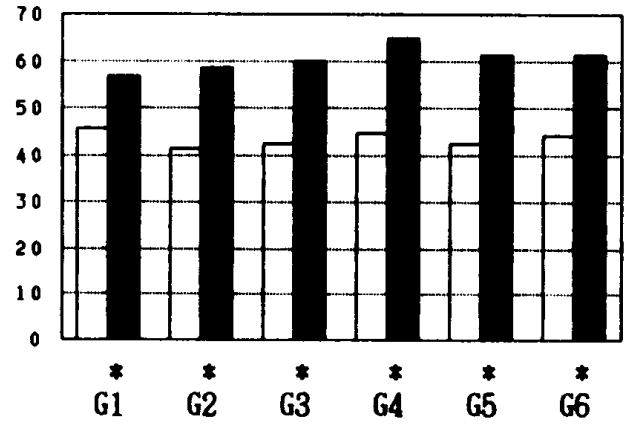

$\mathrm{F} 1=99.93^{* *}, \mathrm{~F} 2=0.63, \mathrm{IN}=0.56$

body fat

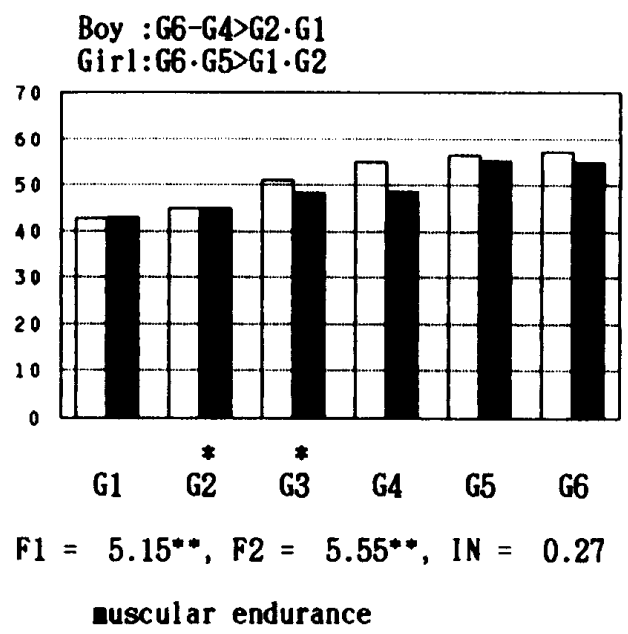

nuscular endurance 
weight, chest-girth, and skinfold thicknesses in the back part of the upper-arm (BUA) and the lower part of the shoulder blade (LSB) with standard values ${ }^{38)}$, similar trends were also confirmed in the present study. Significant growth with age was found in body weight, body girth of chest, upper arms and lower limbs, and LBM, but not in any variable of body-width and body fat. Height showed a significant increase with age only in boys. Because the genetic influence of increase of height and bone-width is stronger than training ${ }^{34)}$, it is difficult to think of growth as influenced by swimming training. The age-stage in which the increase of height stops is $18-19$ years in boys, and 16-17 years in girls ${ }^{34,38)}$, and the increase of height in the age-stage of 13-19 years is greater in boys ${ }^{34)}$. It has been reported that there are significant relations between physique and swimming performances ${ }^{23)}$, and that sex differences ${ }^{25}$ ) in these relations exist. The present results sug-

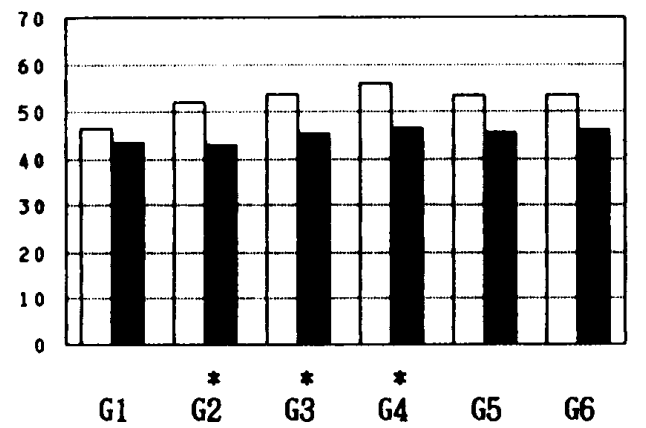

$F 1=15.97^{* *}, F 2=0.90, I N=0.23$

balance

Boy :G6 $\cdot G 5>G 3-G 1, G 4>G 2 \cdot G 1$

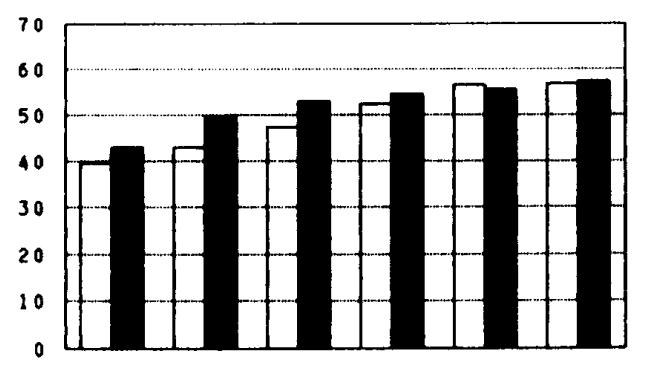

G1 $\quad$ G2 $\quad$ G3 $\quad$ G4 $\quad$ G5 $\quad$ G6

$\mathrm{F} 1=2.17, \mathrm{~F} 2=6.54^{* *}, \mathrm{IN}=0.35$

agility of lower linbs

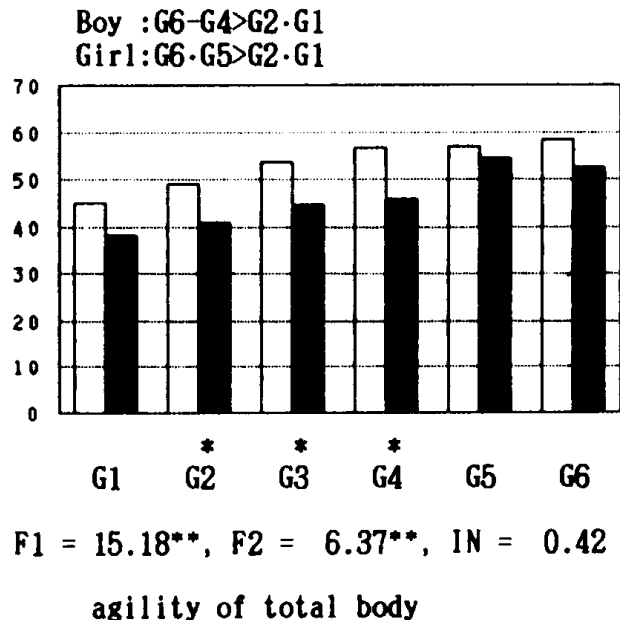

Boy : $\mathrm{G} 6-\mathrm{G} 4>\mathrm{G} 3>\mathrm{G} 2 \cdot \mathrm{G} 1$

Girl: $\mathrm{G} 6-\mathrm{G} 4>\mathrm{G} 2 \cdot \mathrm{G} 1, \mathrm{G} 6>\mathrm{G} 3, \mathrm{G} 3>\mathrm{G} 1$

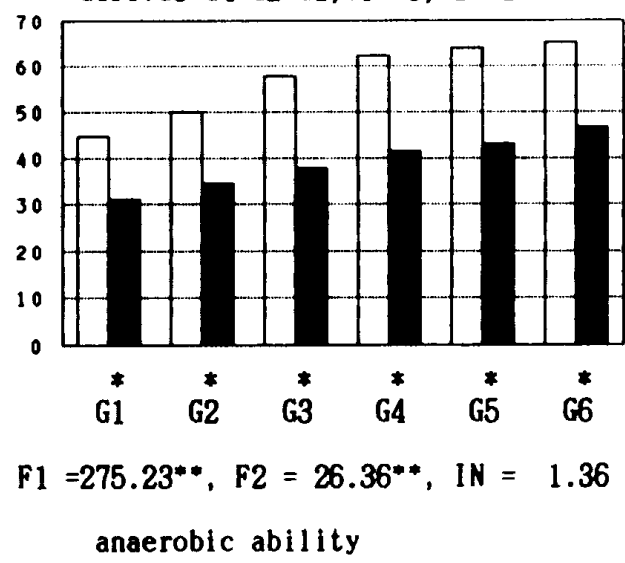

Groups G1-G6 are the same as those in Table 1. $\mathrm{a}=$ boys $\boldsymbol{a}=$ girls

Signes of F1, F2, and IN are the same as those in Table 2.

* above G1-G6 means a significant sex difference.

$\mathrm{G} 4>\mathrm{G} 2 \cdot \mathrm{G} 1$ means value of $\mathrm{G} 4$ is significantly greater than those of $\mathrm{G} 1$ and $\mathrm{G} 2$.

G6-G4 $>$ G3-G1 means values for 3 groups of G4-G6 are significantly greater than those for 3 groups of G1-G3. ${ }^{*} \mathrm{p}<0.05,{ }^{* *} \mathrm{p}<0.01$.

Fig. 1 Test results among means by age and sex for each physical fitness factor 
gest that also in the case of competitive swimmers doing hard-swimming training a similar increase of height and similar sex difference in this increase are present like in ordinary people. There is a close relation between enhanced swimming performance and the increase of height ${ }^{17,22)}$. It can be inferred that young swimmers with great height and who are still growing, increase their performance remarkably and continue activity as competitive swimmers.

Body bulk and LBM have a close relationship with the development of muscular strength ${ }^{31)}$. The component tissue of body is divided broadly into activity tissue (LBM) and inactivity tissue (body fat) and both are greatly influenced by circumstance-conditions like training and nutrient intake $^{31)}$. In the age-stage from 13 to 19 years skinfold thicknesses in BUA and LSB increase considerably, especially in girls ${ }^{34)}$. Also, it is reported that body fat for competitive swimmers changes according to the season ${ }^{3,4,13)}$. The present results showed a significant increase with age in LBM and body weight, but not in body fat or either skinfold thickness. This means that the proportion of muscular quantity to the whole body weight increased with age. Generally, girls have more body fat, and boys have more developed muscle and greater body height in the same age-stages ${ }^{18,24,34,38)}$, with these trends becoming more marked with age when the sex difference enlarges ${ }^{34,38)}$. Also in the present results, significant sex differences in all physique meausres were found, and the existence of sex differences similar to those of ordinary people in their growth was confirmed.

From the above-mentioned discussion, for competitive swimmers doing hard swimming training continuously, the following inferences will be made; similar sex differences in the whole physique side and a similar growth in body linearity and body bulk as found in ordinary people of the same age exist. But, swimmers have less body fat, and do not show major changes in body fat with age like ordinary people. Therefore, fitting pattern of body fat and the change of body density with age in swimmers will differ from those of ordinary people.

On the other hand, because body fat contributes to increase buoyancy in the case of swimming, being different from many competitive sports on land, more body fat is not always a minus factor ${ }^{29,31)}$. Although hard swimming training enhances the development of cardio-vascular function and muscular strength, or swimming skill, it also contributes to the decrease of extra body fat. A minus point of the decrease of buoyancy to the achievement of speed swimming seems to be set aside by the increase of impulsion and the endurance of high swimming speed (by the above-mentioned development of physical fitness elements) in addition to the reduction of water resistance by the improvement of swimming skill. Therefore, the development of physical fitness and skill by swimming training seems to contribute to the improvement of swimming performances more than the decrease of body fat.

\section{B. Muscular strength}

To swim fast, it is necessary to produce greater propulsion and endure high swimming speed in addition to lessening water resistance as much as possible. Since water resistance increases in proportion to the square of about 2 of swimming velocity ${ }^{36)}$, to get greater impulsion overcoming it, the development of the muscular strength of the limbs, especially the upper limbs which perform the main role when moving in water, is indispensable. Previous studies determined that competitive swimmers as compared with agematched ordinary people have superior muscle of limbs relating highly to the achievement of speed swimming ${ }^{18,20,24,26)}$ and there is a close relation- 
ship between the improvement of swimming speed and the development of muscular strength ${ }^{15,17,22,23)}$. It is considered that the whole muscular strength and muscular endurance for competitive swimmers develop to some extent because swimming is an exercise using the whole body and it is one of the representative endurance exercises. However, the developement of muscular strength not contributing directly to speed swimming is a minus factor on swimming performance ${ }^{6)}$. The present results showed that all variables of static strength and muscular endurance in both sexes develop with age. From comparing between means, it can be inferred that the development of strength with age is greater in boys, with sex differences in the degree of its development in each age-stage present. A significant development with age in vertical and standing broad jumps representing leg power was found only in boys. The developmental sex-difference in leg power seems to be greater than that in static strength and muscular endurance. In the case of swimming, opportunities to exert explosive strength of the legs are very few except for starting. Therefore, exercise stimulus needing the development of this kind of strength seems to be very scarce and low. In this age-stage the degree of secretion of male hormones differs considerably between the sexes ${ }^{34)}$. Therefore, even if the intensity of exercise stimulus was the same, its effects would not always be the same in both sexes. Furthermore, body weight increasing with age seems to be a minus factor to their performance. By the influence of such complex factors, a sex difference in the development of leg power with age seems to be found. Generally, boys are superior in muscular strength to girls ${ }^{24,34,38)}$. Also in the case of competitive swimmers, similar sex differences in all kinds of strength were confirmed.

\section{Nervous function}

There are only a few studies on nervous function of competitive swimmers. Demura et al. ${ }^{19}$ ) studied the nervous function of college competitive swimmers, and reported that insignificant differences between crawl, back, breast, and butterfly strokes were found in nervous function factors of agility of limbs, agility of trunk, dynamic balance, static balance, and agility of the whole body. Furthermore, Demura ${ }^{24}$ determined that among various nervous functions, junior high school competitive swimmers as compared with ordinary students of a similar age, are superior in agility and reaction of the whole body, rather than in agility of limbs and balance. Generally, the reaction time of the whole body does not show a large change with age in any age-stage from 13 18 years $^{38)}$. However, the reaction time of the whole body and squat-thrust in this study showed significant development with age. It is said that quick action is mainly determined by velocity of nerve transmission and muscle contraction, and an individual difference in this kind of test depends mainly on the latter factor ${ }^{42)}$. High concentration and quick reaction of the whole body at the start of competitive swimming and the speedy bending and extension action of the whole body at turning were needed, respectively. In competitive swimming in which rank is frequently determined by a slight difference of the touch, speedy starting and turning are important factors influencing the outcome ${ }^{37)}$. Competitive swimmers do repeat practice focusing on quick and speedy starts and turns everyday. It is inferred that they are superior in explosive reaction of the whole body or in the agility of bending and extension of the whole body measured by squat and thrust test among various agilities of the total body, and their abilities develop with age.

Significant sex differences were found in tests of side-steps, squad-thrusts, and toe-standing 
balance with eyes closed. Similar results also in the former study using college competitive swimmers were reported ${ }^{20)}$. The achievement abilities of these tests are generally superior in boys as compared with girls ${ }^{38)}$. Therefore, it is noted that like college competitive swimmers ${ }^{20)}$, significant sex difference in stepping test measuring the agility of limbs was not found. In speed swimming of crawl and back strokes, speedy and powerful kicks are required. Steppings are similar to kick action of the above-mentioned strokes in that they move the lower-limbs quickly and mutually. Competitive swimmers repeat their kick practice from a lower age-stage for several years.

\section{Joint function (flexibility)}

Flexibility is considered to be one of the more important factors relating to the achievement of speed swimming ${ }^{5-10,21,30)}$. Swimmers develop more flexibility as compared with ordinary people of a similar age ${ }^{7,24)}$. Among various physical fitness elements, generally girls' flexibility is superior to that of boys' $18,24,34,38$ ).

The present results did not show significant changes with age in any flexibility of various body parts. These results are largely consistent with those obtained in previous studies ${ }^{18,24)}$ using welltrained swimmers. This seems to depend on the following reasons; flexibilities needed in speed swimming are already considerably developed in the age-stage of 12-13 years which was the lowest age in this study. And swimming training throughout the year for 3 years was continued. Their developed flexibility was maintained in each age-stage after 12 years. Therefore, it seems that the developmental change of flexibility with age as shown in ordinary people did not occur ${ }^{38}$.

On the other hand, significant sex differences were found in flexibility of shoulder and ankle joints, but not in that of any trunk joint. Regarding the sex difference of flexibility for swimmers consistent results have not always been obtained $^{18,20,24)}$. It is reported that flexibility is improved even by training for a relatively short period $^{28,30)}$, and its development is different in each stroke ${ }^{19}$. Besides, flexibility shows some variation according to differences in characteristics of the subjects (age and skill level) and by the measuring time even in the same body parts and method. In addition, some flexibilities are related highly to the achievement of speed swimming whereas others are not. Also sex differences in the development-possibility of various flexibilities exist. These facts seem to produce inconsistencies in the results.

\section{E. Cardio-vascular function}

Swimming is one of the most representative aerobic exercises, and the practice of hard swimming training over several years seems to contribute to the development of cardio-vascular function ${ }^{5,14,27,37,41)}$. Demura et al. ${ }^{24)}$ performed a comparative study on physical fitness between junior high school competitive swimmers and ordinary students of a similar age, and determined that swimmers have superior cardio-vascular function. This was true even for girl-swimmers compared with ordinary boys of the same age. The results obtained in this study largely agree with those in former studies ${ }^{14,27,37,41)}$, also with regard to sex differences.

The development of cardio-vascular function is one of the most important factors influencing swimming performances ${ }^{1)}$. Regarding sex difference of cardio-vascular function a similar trend to that found among ordinary people was also seen in the case of swimmers in this study, while especially in aerobic ability, significant sex differences in values per weight were not found. Generally, values of $\dot{\mathrm{VO}}_{2 \max } / \mathrm{w}$ are higher in boys than in girls ${ }^{38)}$. Girl-swimmers in this study have undergone almost the same training as boys. So the for- 
mer's aerobic ability seems to have developed considerably.

On anaerobic ability from the present results boy-swimmers are considered to be superior to girl-swimmers. Anaerobic ability contributes to swimming performance more in the case of shorter distances, with the contribution of aerobic ability becoming greater gradually with the extension of distance ${ }^{1)}$. Sex differences on cardio-vascular function and the difference of the contribution of both abilities to performance in different distances are considered to be one of the important factors producing sex differences in swimming performance.

On the other hand, generally the peak of development of $\mathrm{VO}_{2 \max }$ is an age-level of $16-17$ years for girls, but for boys it develops until close to 20 years ${ }^{34,38)}$. Also in the present results similar trends were found. In a comparison between junior high school and high school boy swimmers based on cross-sectional data, $\mathrm{PWC}_{\max }$ and $\dot{\mathrm{V}} \mathrm{O}_{2 \max }$ showed higher values in the latter group, but statistically significant differences were not found. Accordingly, it can be inferred that the developmental possibility of this ability was low even if they continued similar training ${ }^{24)}$. In the present results based on the longitudinal and cross-sectional data, significant improvement in their absolute values was found. Significant development with age in both sexes was found in anaerobic ability. Although an increase in the training quantity every year, in preparation for the national athletic meet, also seems to be of some influence from the present results, it can be inferred that their cadio-vascular function, which develops sufficiently for their age (especially the anaerobic ability), develops further with age due to continuous swimming training.

In summary, the same sex differences and the same development with age compared with ordinary people of a similar age in many physical fit- ness elements such as physique, static strength, muscular endurance, power, agility, balance, aerobic ability, and anaerobic ability were confirmed. But, significant sex differences and developmental changes with age in trunk bending flexibilities and aerobic ability per body weight, and significant changes in body fat and other flexibilities with age were not found. These results were different from those found in ordinary people. Therefore, regarding the development of these physical elements, it was suggested that a trend differing from that of ordinary people exists. It is speculated that the differences in growth and development of physical fitness elements depend on continuous swimming training for a relatively long period of time.

\section{References}

1) Asano, K. (1976) Text book of work physiology. Taishukan: Tokyo, pp. 204-235. 〈in Japanese : 线野勝己訳, 運動生理学〉, 〈Astrand, P. O. and Rodahl, K. (1970) Text book of work physiology. McGraw-Hill, Inc., Original work published in New York $>$.

2) Brozek, J., Grande, F., Anderson, J. T. and Keys, A. (1963) Denshitometric analysis of body composition. Review of some quantitative assumptions. Ann. N.Y. Acad. Sci., 110: 113-140.

3) Bruce, W. M. and Marina, R. M. (1985) Changes in body composition and physique of elite university-level female swimmers during a competitive season. J. Sports Sci., 3: 33-40.

4) Clarke, D. H. and Vaccro, D. (1979) The effect of swimming training on muscular performance and body composition in children. Res. Quart., 50: 917.

5) Corfdain, L., Alan, T. and Debbie, M. (1990) Lung volumes and maximal respiratory pressures in collegiate swimming and runners. Res. Quart., 6(1): 70-74.

6) Counsilman, J. F. (1968) The science of swimming. Pretice Hall., 204: 278-308.

7) Counsilman, J. F. (1977) Competitive swimming manual for coaches and swimmers. Counsilman, Co. Inc., 125-130. 
8) Cureton, T. K. (1930) Mechanics and kinesiology of swimming (the crawl flatterkick). Res. Quart., 1: $87-121$.

9) Cureton, T. K. (1941) Flexibility as an aspect of physical fitness. Res. Quart., 12: 381-391.

10) Cureton, T. K. (1961) Physical fitness of champion athletes. Univ. of Illinois, 11-60.

11) Cureton, T. K. (1963) Improvements in physical fitness associated with a course of U.S. navy underwater trainees, with and without dietary supplements. Res. Quart., 34: 440 447.

12) Davis, J. F. (1959) Effect of training and conditioning for middle distance swimming upon various physical measures. Res. Quart., 30: 339-412.

13) Dickson, C. A. (1971) The effects of swimming instruction method on selected aspects of physical fitness. Doctoral dissertation, University of Texas.

14) Dick, B. V. L. (1968) A comparative study of distance, interval and mixed methods of training for competitive swimming. Indiana. Univ.

15) Demura, S. and Matsuura, Y. (1979) The relationship of muscular strength with swimming performance. Jap. J. Phys. Educ., 24(1): 59 69, (in Japanese：出村慎一・松浦義行，筋力と水泳パフ ォーマンスとの関係〉.

16) Demura, S. and Matsuura, Y. (1982) Flexibility test battery for college male swimmers. Jap. J. Phys. Fitness Sports Med., 31: 94-102, 〈in Japanese：出村傎一・松浦義行，大学男子水泳選 手のための柔軟性組テスト〉.

17) Demura, S. (1983) The sexual difference of factorical structure of swimming ability in welltrained junior high school swimmers. Japan J. Phys. Educ., 27(4): 287-299. 〈in Japanese : 出村 慎一，水泳能力因子構造の性差〉.

18) Demura, S. (1983) The sex difference and grade difference in anthropometric characteristics, muscular strength, and flexibility: junior high school swimmers. Jap. J. Phys. Fitness Sports Med., 32: 8-16. 〈in Japanese : 出村嫃一，中学生水泳選手の 形態，筋力，及び柔㜞性の性差 ·学年差の愉討〉.

19) Demura, S., Matsuura, Y. and Tanaka, K. (1984) Comparison of physique, muscular, flexibility, and neuromuscular function among different swimming strokes of swimmers. Japan J. Phys. Educ., 29 (1): 25-34. 〈in Japanese : 出村慎一一松浦義行 ·田中喜代次，泳法別に見た水泳選手の形態，筋
力，柔軟性，及び神経機能の比較〉.

20) Demura, S. (1986) Sexual differences in physique, physical fitness, and swimming skill of college swimmers. Japan J. Phys. Educ., 31 (2) : 151161. (in Japanese : 出村惧一, 大学競泳選手の体 格，体力及び神経機能の性差〉.

21) Demura, S. (1989) Relationship of physique with crawl swimming performance in competitive college male swimmers. Bull. Faculty of Education, Kanazawa University, 38: 135-143.

22) Demura, S. (1990) Factorial structure of swimming ability and its sexual difference in well trained schoolchild swimmers. Jap. J. Phys. Educ., 35(3) : 219-230.

23) Demura, S. (1990) Contribution of physique and muscular strength to pull swimming force and swimming performance in school-boy swimmers. Bull. Faculty of Education, Kanazawa University, 39: 187-196.

24) Demura, S., Matsuzawa, J., Naka, H. and Kita, I. (1991) Physical characteristics in well-trained young swimmers. Jpn. J. Phys. Fitness Sports Med., 40: 278-287. 〈in Japanese : 出村慎一。 松沢甚三郎·中比呂志·北一郎，中学・高校競 泳選手の身体特性〉。

25) Demura, S. (1992) The sexual differences of the contribution of physique to crawl swimming performance in competitive college swimmers. Bull. Faculty of Education, Kanazawa University, 41: 19-26.

26) Faulkner, J. A. (1966) Physiology of swimming. Res. Quart., 37: 41-54.

27) Giese, W. K. (1965) The effects of a longitudinal program of swimming interval training upon selected physiological parameters of the prepubescent male and female. The Florida. State. Univ.

28) Healey, J. H. (1970) A comparative study to determine the relationship between plantar flexion at the ankle joint and success in selected skills in swimming. Doctoral dissertation, Univ, of Utah.

29) Ikegami, H., Shigeeda, T., Kuyama, J., Nomura, T., Kurokawa, T. and Goto, S. (1983) Comparison of $\mathrm{VO}_{2}$ for buoyancy and propulsion during swimming between male and female. Japan J. Phys. Educ., 28-1: 33-42. (in Japanese : 池上 晴夫·重枝武司 · 久山順子・野村武男 · 黑川武志 ・後藤嫃二，水泳における浮くためのエネルギー と推進のためのエネルギーの男女比較〉. 
30) Jorndt, G. T. (1973) The effects of exercise on ankle flexibility and on three swimming kick, Doctoral dissertation, Univ. of Utah.

31) Kitagawa, K. (1984) Fat mass and physical fitness in overweight person. Kyourin bookstore: Tokyo, pp. 33-46, 103-116. 〈in Japanese : 北川 䔄, 肥满者の脂肪量と体力〉。

32) Matsuda, I. and Ono, M. (1974) The measurement method of physical fitness for sportsmen. Taishukan: Tokyo, pp. 77-112, 230-232. (in Japanese：松田岩男・小野三嗣，スポーツマンの 体力測定〉.

33) Matsui, M., Mizuno, T. and Ehashi, S. (1982) Measurement of physical fitness of sportsmen. Taishukan shoten: Tokyo, pp. 1-25. 〈in Japanese : 松井三雄·水野忠文・江橋慎四郎, 体 育測定法〉.

34) Matsuura, Y. (1983) Development of Physical Fitness. Asakura shoten: Tokyo, pp. 68-122. 〈in Japanese : 松浦義行, 体力の発達〉.

35) Nagamine, S. (1979): Obesity and the method of reducing weight. In., Nagamine, S., Sport, Energy and Nutrition, Gendaino Sports-Kagaku, Taishukan, Tokyo, 259-283 〈in Japanese : 長峰 晋吉, 現代のスポーツ科学講座 第 2 巻一スポー ツとエネルギー・栄埌一。

36) Nomura, T. (1984) The scientific base of water sports. In: Asami, T., Miyashita, M. and Watanabe, H. (Eds.) Physical Education and Sports in the future, 14. Koudansha: Tokyo, pp. 6-19.〈in Japanese：野村武男, 現代体育・スポー 学体系, 第14巻〉。

37) Nomura et al. (1986) Swimming faster. Baseball magazine-sha: Tokyo, pp. 193-224, 256-266, 282-315. 〈in Japanese：野村武男他訳, スイミン
グファースター〉, 〈Maglischo, E. W. (1982) Swimming faster. Mayfield Pub. Co. Original work published in California $>$.

38) Physical Fitness laboratory, Tokyo Metropolitan University (Ed.) (1990) Physical fitness standards of Japanese people, 4th ed. Fumaido: Tokyo. 〈in Japanese : 東京都立大学身体商性学研 究室編, 日本人の体力標淮檤 第 4 版 $>$.

39) Ross, D. T. (1970) Selected training procedures for the development of arm extensor strength and swimming speed of the sprint crawl stroke. Doctoral dissertation, Univ. of Arkansas.

40) Sprague, H. A. (1976) Relationship of certain physical measurements to swimming speed. Res. Quart., 47: 810-814.

41) Steinmetz, C. W. (1975) Comparison between the grab start and the conventional start in competitive swimming. Ohio State Univ.

42) The Special department of Measurement and evaluation in Japanese Society of Physical Education (Ed.) (1981) Diagnosis and evaluation of physical fitness. Taishukan: Tokyo, pp. 145-168. 〈in Japanese：日本体育学会測定評価専門分科会 編, 体力の診断と評価〉.

43) Wade, C. E. (1976) Effect of a season's training on the body composition of female college swimmers. Res. Quart., 47: 292-295.

44) Zaciorsky, V. M. und Safarjan, I. G. (1972) Untersuching von Factoren zur Bestimmung der maximalen Geschwindigkeit im Freistilschwimmen. Theorie und Praxis Korper Kultur, 695-708.

(平成 6 年 8 月 22 日受付 平成 7 年 4 月 22 日受理 